\title{
The Implementation of Social Media Marketing and Customer Relationship Management as a Competitive Advantage in Private Higher Education to Increase Student Loyalty
}

\author{
Wendi Usino ${ }^{1}$, Dewi Murtiningsih ${ }^{2}$ \\ \{wendi.usino@budiluhur.ac.id ${ }^{1}$, dewi.murtiningsih@ @udiluhur.ac.id² \\ Faculty of Information Technology, Budi Luhur University, Jl. Raya Ciledug Raya, Jakarta, \\ Indonesia ${ }^{1}$, Faculty of Economy and Business, Budi Luhur University, Jl. Raya Ciledug Raya, Jakarta, \\ Indonesia $^{2}$
}

\begin{abstract}
The purposes of the study is to determine the influence of social media marketing application to the loyalty of students and to competitive advantage, to determine the influence of the application of competitive advantage to student loyalty, to determine the influence of social media marketing application to the loyalty of students through competitive advantage, to know the influence of customer relationship management application to competitive advantage and to student loyalty, to know the influence of customer relationship management application to student loyalty through competitive advantage. This research includes explanatory research with the sample of research using purposive sampling with total 110 respondents of undergraduate students (S1) in five faculties at Budi Luhur University Jakarta which have been taking at least semester 4. Data were analyzed with Structure Equation Modeling (SEM) consisting of measurement model and structural model of AMOS program. Based on the results of research can be seen that, social media marketing does not affect the loyalty of students and the competitive advantage, competitive advantage affect the loyalty of students, competitive advantage does not mediate the influence of social media marketing to loyalty students, customer relationship management influential against competitive advantage and does not affect student loyalty, and competitive advantage mediate the influence of customer relationship management on student loyalty.
\end{abstract}

Keywords: Social Media Marketing, Customer Relationship Management, Competitive Advantages, Student Loyalty.

\section{Introduction}

The rapid growth and growth of private universities in Indonesia, especially in Jakarta, makes private universities implement the right business strategy in order to survive in the business world. Private universities should continually add new ways or breakthroughs in terms of interacting with their customers. In this case "private college customers" are students. Various strategies are applied to create competitive advantage. Social media marketing and customer relations management is a strategy applied to be successful in the face of competition and to create loyalty. 
Research on loyalty has been widely studied, but research on the application of social media marketing and customer relationship management to loyalty through competitive advantage has not been widely studied in universities. The reason for this research is using private university object because in the previous research many use the object of manufacture. The selection of private universities is due to the increasingly dynamic development of private universities so that private universities must have new marketing strategies in marketing their products and have products that are differentiated and make their customers become loyal. The question is it true that the application of social media marketing and customer relationship management has consistently affected loyalty?

This research was conducted to develop model of social media marketing application and customer relationship management to loyalty by entering the mediation variable of competitive advantage. This research intends to fill the gap of research as follows: The inconsistency of the findings of previous research, which examines the relational relationship between social media marketing to loyalty and customer relationship management to loyalty needs to be done in service companies such as universities considering the previous research is mostly done in manufacturing; Adding the results of social media marketing research on loyalty and customer relationship management to loyalty in the field of education, especially private universities.

According to Porter (1998) by optimizing his strategy for a particular target segment, colleges that use focusing excellence seek to achieve competitive advantage in a narrow target segment despite not having overall competitive advantage. By serving a narrow and exclusive market segment, a college is expected to gain competitive advantage, enabling it to achieve institutional success and market success [20].

The most important for private universities is how to understand and meet the needs and wishes of students, so that the university can develop products, prices, distribution, promotion of service officers, service process, and the provision of physical facilities companies that can expand the market or increase market share college private. To capture new customers and retain customers, there needs to be a high commitment both in terms of funds and human resources and sophisticated technological support to ensure that the product quality is in accordance with the customers' wishes such as social media marketing on campus where they are studying and can give students satisfaction students become loyal with the implementation of customer relationship management.

\section{Framework And Hypotheses Concept}

Research conducted by Erdogmus and Cicek (2012); Murtiningsih and Ali Murad (2016) shows that social media marketing has an effect on brand loyalty [4],[12],[16]. In addition, the influence of social media marketing on brand loyalty can increase the attention of academic marketing and practitioners in marketing [11],[15],[24]. Based on the above opinion, it can be built as follows hypothesis:

H1: Social media marketing has an effect on loyalty.

The results of research conducted by Popescu and Alecsa (2015) states that social media marketing influence on competitive advantage. Social media is a strategy that can help companies in the face of excellence. Through social media companies can have differentiation that is not owned by competitors. Based on previous research, hypothesis can be made as follows: 
H2: Social media marketing has an effect on competitive advantage.

The results of research conducted by Pudyanarti and Yuniati (2016) show evidence that competitive advantage affects loyalty [21]. The essence of competitive strategy can be described as a process of how firms build and develop their strategic resources that have the potential to produce competitive advantage, whichever advantages can be ambiguous on the one hand as instruments for performance and on the other as instruments to neutralize competing assets and competencies owned by a competitor. This process which consciously developed from time to time will in essence be a strong foundation for the achievement and development of sustainable competitive advantage [5]. Based on that opinion, the hypothesis is as follows:

H3: Competitive advantage affects loyalty.

Based on the results of research conducted by Erdogmus and Cicek (2012); Murtiningsih and Ali Murad (2016) show that social media marketing has an effect on loyalty, while research conducted by Popescu and Alecsa (2015) shows the result that social media marketing has an effect on competitive advantage, and research conducted by Pudyanarti and Yuniati (2016) evidence that competitive advantage affects loyalty. Referring to the concepts and results of previous research, this study examines the role of competing keuggulan in mediating the influence of social media marketing tehadap loyalty, based on the description above, the hypothesis presented are as follows [3],[16],[21],[22]:

H4: Social media marketing affects loyalty through competitive advantage

Several previous studies have provided evidence that there is an influence between the implementation of Customer Relationship Management (CRM) with the achievement of competitive advantage. Alipour and Mohammadi (2011) in his research concluded that CRM is very effective in order to achieve competitive advantage [1]. This relationship is reinforced by the results of research Nguyen, Sheriff, and Newby (2007) who said that the application of the right CRM can improve the company's ability in achieving the company's goal of maintaining customers and achieve competitive advantage over competitors [18]. Another study from Zikmund et al. (2003), said that if our business customers are assets, then we must think about the business customers now and in the future [25]. Verhoef and Lemon (2013) states that customer relationship management is a positive strategy in relationships with customers and can increase customer commitment and loyalty [23]. Other research conducted by Hunt, Arnett and Madhavaram (2006); Morgan and Hunt (1994); lee and kim (2014), Thomas and Sullivan (2005) argue that relationship marketing is the best way to identify customers like what customers need and can make customers loyal. Based on this opinion, the hypothesis can be constructed as follows [8],[9],[10],[13],[14]:

H5: Customer relationship management influences competitive advantage.

Another study conducted by Ndubis (2006) under the title "Relationship Marketing and Customer Loyalty" shows that there is a positive and significant relationship between relationship marketing and customer loyalty (customer loyalty) [17]. The results of this study are similar to the results of research conducted by Padmavathy, Balaji and Sivakumar (2012) where the results in the study showed that CRM has a significant positive effect on consumer loyalty [19]. Based on this opinion, it can be hypothesized as follows:

H6: Customer relationship management affects loyalty.

Based on research that has been done by Alipour and Mohammadi (2011); Nguyen, Sheriff, and Newby (2007); and Zikmun et al. (2003) states that customer relationship management affects the competitive advantage [1],[[6],[18],[25]. And the results of research conducted by Ndubis (2006); and Padmavathy, Balaji and Sivakumar (2012) have provided evidence that customer relationship management affects customer loyalty [17],[19]. Referring 
to the concepts and results of previous research, this study examines the role of competing keuggulan in mediating the influence of customer relationship management tehadap loyalty, based on the description above, the hypothesis presented are as follows:

H7: Customer relationship management affects loyalty through competitive advantage.

\section{Methodology}

This research is included in the explanatory research category. Objects studied in this study are Social media marketing variables, Customer relationship management, Competitive Advantages, Loyalty of students, and the subject of this study are undergraduate students at least 4th semester who are in the five faculties at Budi Luhur University Jakarta. The research sample is set at 100 plus $10 \%$, so the total sample is all (n) to 110 students. With consideration if there is a defect in collecting the remaining questionnaires still meet the minimum rules of sample size. If based on the proportion then the number of student samples of each faculty can be described in Table 1 below:

Table 1. The number of Sample in Research.

\begin{tabular}{|c|c|c|c|}
\hline Fakultas & Jumlah & $\begin{array}{l}\text { Prosentase } \\
\%=(\Sigma @ \mathrm{~F} / \\
\Sigma \mathrm{JT}) \mathrm{X} \\
100 \%\end{array}$ & $\begin{array}{l}\text { Sampel } \\
\mathrm{S}=\% \mathrm{X} \\
\Sigma \mathrm{SK}\end{array}$ \\
\hline FTI & 606 & $33 \%$ & 36 \\
\hline FIKOM & 566 & $30 \%$ & 33 \\
\hline FEB & 484 & $26 \%$ & 29 \\
\hline FISIP & 125 & $7 \%$ & 8 \\
\hline FT & 77 & $4 \%$ & 4 \\
\hline Jumlah Total & 1.858 & $100 \%$ & 110 \\
\hline
\end{tabular}

The model of this research analysis using Structure Equation Model (SEM) with AMOS application (Analysis of Moment Structure). The research variables with their indicators are shown in detail in Table 2.

Table 2. Sources Referred for the Measurement.

\begin{tabular}{cccc}
\hline No & Variable & Indicator & Source \\
\hline 1 & Social Media & Advantageous & Erdogmus \& \\
& Marketing & campaigns; & Cicek (2012) [4] \\
& Relevant & \\
& contents; & \\
& Popular & \\
& contents; & \\
& Various & \\
& platform; & \\
& Application & \\
& on social & \\
& & media \\
& &
\end{tabular}




\begin{tabular}{|c|c|c|c|}
\hline 2 & $\begin{array}{c}\text { Customer } \\
\text { Relationship } \\
\text { Management }\end{array}$ & $\begin{array}{l}\text { Identify; } \\
\text { Acquire; } \\
\text { Retain; } \\
\text { Develop }\end{array}$ & $\begin{array}{c}\text { Kotler \& } \\
\text { Amstrong(2004) } \\
{[12]}\end{array}$ \\
\hline 3 & $\begin{array}{l}\text { Competitive } \\
\text { Advantage }\end{array}$ & $\begin{array}{l}\text { Makes } \\
\text { Reguler } \\
\text { repeat } \\
\text { purchase; } \\
\text { Purchase } \\
\text { across } \\
\text { product and } \\
\text { service line; } \\
\text { Refer other; } \\
\text { Demostrates } \\
\text { an immunity } \\
\text { to the pull of } \\
\text { the } \\
\text { competition }\end{array}$ & $\begin{array}{c}\text { Griffin (2009) } \\
{[6]}\end{array}$ \\
\hline 4 & $\begin{array}{l}\text { Student } \\
\text { Loyalty }\end{array}$ & $\begin{array}{l}\text { Behaviour } \\
\text { measures; } \\
\text { Measuring } \\
\text { swith cost; } \\
\text { Measuring } \\
\text { satisfaction; } \\
\text { Measuring } \\
\text { liking brand; } \\
\text { Measuring } \\
\text { commitment }\end{array}$ & $\begin{array}{c}\text { Bastian (2014) } \\
\text { [2] }\end{array}$ \\
\hline
\end{tabular}

\section{Analysis And Findings}

Data analysis techniques using Structure Equation Modeling (SEM) using Analysis of Moment Structures (AMOS), was used to analyze the causal relationship between social media marketing, customer relationship management, competitive advantage and student loyalty.

The model has a good Discriminant Validity if the correlation value of each variable is below 0.85 [7]. The correlation value for each variable in this study is shown in Table 3 below:

Table 3. Inter-variable Correlation Value. 


\begin{tabular}{lllr}
\hline & & & Estimate \\
\hline CRM & $<-->$ & KB &, 632 \\
CRM & $<-->$ & LM &, 596 \\
CRM & $<-->$ & SMM &, 825 \\
KB & $<-->$ & LM &, 658 \\
KB & $<->$ & SMM &, 578 \\
LM & $<-->$ & SMM &, 635 \\
e16 & $<-->$ & e14 &, 351 \\
\hline \multicolumn{3}{r}{ Source: Output SEM AMOS 2017 }
\end{tabular}

Based on the data, we do not find any problems related to discriminant validity. This is because the correlation value of each variable is below 0.85 . It can be concluded that all constructs in the estimated model meet the criteria of discriminant validity.

\subsection{Composite Reliability}

The estimation results on the value of composite reliability for social media marketing (SMM), customer relationship management (CRM), competitive advantage (KB), and student loyalty (LM) as described in Table 4 below:

Table 4. Composite Reliability Value.

\begin{tabular}{cc}
\hline Variable & CR \\
\hline SMM & 0,824 \\
CRM & 0,8 \\
KB & 0,789 \\
LM & 0,813 \\
\hline Source: Output SEM AMOS 2017
\end{tabular}

Based on the reliability analysis in Table 4 above, make sure that all constructs have good reliability. This is because each construct / variable has a value of composite reliability above 0.7. Thus it can be concluded that all variables have a good composite reliability value.

\subsection{Test of Structural Model}

Structural model testing performed to see the relationship between variables, Figure 1. Below shows full model structure equation analysis, is as follows:

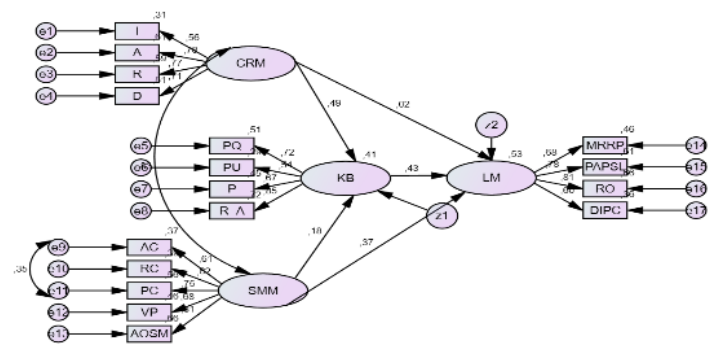


Fig. 1. Full Model Structural Equation Analysis. Source: Output SEM AMOS 2017.

The result of inner weight above shows that the strength of social media marketing (SMM) pathway affects student loyalty (LM) of 0.02 ; social media marketing (SMM) affects competitive advantage (KB) of 0.46 ; competitive advantage (KB) affect student loyalty (LM) of 0.43 ; customer relationship management (CRM) affects competitive advantage (KB) of 0.18 ; customer relationship management (CRM) affects student loyalty $(\mathrm{KB})$ of 0.37 .

\subsection{Hypothesis Testing}

The hypothesis test can be seen in Table 5, below can be seen from the value of Tstatistics. The limit to reject the hypothesis value is submitted to the level of alpha significance at a value of $5 \%$ with a value of $t=1.960$. Here are the results of direct impact testing. Here is the result of t-statistic estimation on result for regression weight.

Table 5. Regression Weight.

\begin{tabular}{|c|c|c|c|}
\hline Direc Effect & $\begin{array}{c}\text { Cooefec } \\
\text { ience }\end{array}$ & Prob. & Description \\
\hline CRM --->KB & 1,985 & 0,047 & Significant \\
\hline SMM -->KB & 0,727 & 0,467 & $\begin{array}{c}\text { None } \\
\text { Significant }\end{array}$ \\
\hline KB --->LM & 2,977 & 0,003 & Significant \\
\hline CRM --->LM & 0,070 & 0,944 & $\begin{array}{c}\text { None } \\
\text { Significant }\end{array}$ \\
\hline SMM --->LM & 1,609 & 0,108 & $\begin{array}{c}\text { None } \\
\text { Significant }\end{array}$ \\
\hline
\end{tabular}

\subsection{Indirect Effect Test}

Indirect influence through indirect effect of influence variable of competitive advantage in influencing influence of social media marketing to student loyalty and influence of customer relationship management to student loyalty through competitive advantage, the presentation result are presented of indirect effect test:

Table 6. Indirect Effect Test Results.

\begin{tabular}{lllcc}
\hline Indirect Impact & $\begin{array}{c}\text { Direct Impact } \\
\text { Cooeficiency }\end{array}$ & $\begin{array}{c}\text { Multiplic } \\
\text { ation } \\
\text { Outcome } \\
\text { of Direct } \\
\text { Effect }\end{array}$ & $\begin{array}{c}\text { Descri } \\
\text { ption. }\end{array}$ \\
\hline CRM -> KB- & CR & KB & 0,198 & Partial \\
$>$ LM & M --- & $--->$ & & $\begin{array}{c}\text { Mediat } \\
\text { ion }\end{array}$ \\
& $>$ & LM & & \\
& KB & 0,37 & & \\
\hline
\end{tabular}




\begin{tabular}{|c|c|c|c|c|}
\hline & 0 & & & \\
\hline $\begin{array}{l}\mathrm{SMM} \mathrm{-->KB} \\
-->\mathrm{LM}\end{array}$ & $\begin{array}{l}\mathrm{SM} \\
\mathrm{M}-- \\
-> \\
\mathrm{KB} \\
0,16 \\
0\end{array}$ & $\begin{array}{l}\text { KB } \\
---> \\
\text { LM } \\
0,37 \\
3\end{array}$ & 0,059 & - \\
\hline
\end{tabular}

\section{Hypothesis Discussion}

\subsection{Social Media Marketing Affects Against: Student Loyalty}

Empirical facts show that social media marketing has no effect on student loyalty. This is not in line with research conducted [4] [16]. The value loading factor is the biggest in the possession of applications on social media, but not yet perceived well by the students. This is because students have not utilized sharing applications between lecturers and students in campus social media, and students have not optimized the use of social media on campus, as evidenced by students do not see share photos of activities published in social media such as blogs, Facebook, and twitter. By optimizing the use of social media marketing at Budi Luhur University Jakarta, it is expected to increase student loyalty.

\subsection{Social Media Marketing Effects Against: Competitive Andvantage}

Based on the analysis shows that social media marketing does not affect the competitive advantage. Based on the empirical results shows the reputation of the institution get the highest score. A good reputation from campus to student is an accumulation of assessment that takes no time. This study is not in line with the results of research conducted by Popescu and Alecsa (2015). Thus the University of Budi Luhur Jakarta should increase the use of social media marketing in order to improve the image of the institution and has a competitive advantage that is not owned by its competitors.

\subsection{Social Media Marketing Effects Against: Student Loyalty}

The results of the analysis show that competitive advantage affects the loyalty of students. This result is in line with research conducted by Pudyanarti and Yuniati (2016). Empirical facts show that a good reputation at Budi Luhur University Jakarta can make students refer to other people / friends / family to study at Budi Luhur University [21]. Recommending a positive experience of college students on campus is one of the loyalty of students.

\subsection{Social Media Marketing Effects Against: Student Loyalty with Competitive Advantage}

The result of analysis shows that there is no influence of mediation from competitiveness variables mediate the influence of social media marketing on student loyalty. Competitive advantage does not become a variable of mediation due to the direct influence between social media marketing to competitive advantage has a value that is not significant and on the influence of competitive advantage to the significant loyalties students. Because the value of indirect influence of social media marketing on student loyalty through competitive advantage 
$(0,059)$ is less than the value of direct influence between social media marketing to competitive advantage $(0,160)$ and competitive advantage to student loyalty $(0,373)$.

\subsection{Cusomer Relationship Management: Influential on Competitive Advantage}

The results of the analysis show that customer relationship management has an effect on competitive advantage. This research is in line with research conducted by Alipour and Mohammadi (2011), Nguyen, Sheriff, and Newby (2007), Verhoef and Lemon (2013), Hunt, Arnett and Madhavaram (2006); Lee and Kim (2014); Morgan and Hunt (1994); Thomas and Sullivan (2005). Empirical facts show that employees of Budi Luhur University who provide services to students with friendly and courteous can improve good reputation for Budi Luhur University Jakarta for its students.

\subsection{Cusomer Relationship Management: Influential with Student Loyalty}

The results of the analysis show that customer relationship management does not affect student loyalty. The results of this study are not in accordance with research conducted [17] [19]. Empirical facts show that the acquisition and recommendation to others is still not well perceived by the students because students assume the employees have not provided good service to the students so students are reluctant to recommend to others / family / friends.

\subsection{Cusomer Relationship Management: Influential on Student Loyalty throuh Competitive Advantage}

Based on the results of analysis shows that the variables of competitive advantage become the mediation variable on the influence of customer relationship management on student loyalty. The result of mediation test shows that the advantage of mediate partly on indirect influence, because the coefficient value of direct influence of customer relationship management to competitive advantage $(0,530)$ and competitive advantage to student loyalty $(0,373)$ is bigger than indirect influence from influence of customer relationship management to student loyalty through competitive advantage (0.198).

\section{Managerial Implication}

Based on the results of the research, there are several suggestions that can be given to the management to increase student loyalty are as follows:

1. Social Media Marketing, Budi Luhur University Jakarta needs to pay attention to the intensity of social media usage as a media campaign, because most of Indonesian people have made social media as part of lifestyle. If this concept is understood and applied by the managers of Budi Luhur University Jakarta in the present situation, then social media can be a force in doing promotion.

2. Customer Relationship Management, By providing services that can meet the expectations of students at Budi Luhur University Jakarta, the students will be more able to tell the ease of service at Budi Luhur University Jakarta, so this makes an emotional bond for students who already have a good relationship.

3. Competitive Advantages, Innovations created should be made sustainably, so it is not easily imitated by other universities

\section{Future Research}


This research is shown to know the factors that influence the loyalty of students at Budi Luhur University Jakarta, by looking at the background of research, justification theory and research methods, it can be said some limitations of this research are as follows: The results of this study cannot be generalized in the case outside the object of Budi Luhur University Jakarta; The results show that the research model is still not optimal, so there needs to be a redevelopment of this research.

Based on the limitations that have been submitted, the research on student loyalty can still be developed further in future research, in developing the relevant variables or constructs in improving student loyalty and not closing increase the larger sample size.

\section{References}

[1]Alipour, M. and Mohammadi, M.., 2011. The Effectof Customer Relationship Management (CRM) on Achieving Competitive Advantage of Manufacturing Tractor. Glob. J. Manag. Bus. Res. $11,26-36$.

[2]Bastian, D.A., 2014. Ananlisis Pengaruh Citra Merek (Brand Image) dan Kepercayaan Merek (Brand Trust) Terhadap Loyalitas Merek (Brand Loyalty) ADES PT. Ade Alfindo Putra Setia. J. Manaj. Pemasar. Petra. 2, 1-9.

[3]Coon, M., 2010. Social Media Marketing: Successful Case Studies of Businesses Using Facebook and YouTube with an In-Depth Look in the Business Use of Twitter", Communication M.A. ProjectNo Title [WWW Document]. URL http://comm.stanford.edu/coterm/projects/2010/maddy coon.pdf (accessed 3.2.12).

[4]Erdogmus, C., Mesut, 2012. impact of social media marketing on brand loyalty. Procedia - Soc. Behav. Sci. 58, 1353-1360.

[5]Ferdinand, A., 2003. Sustainable Competitive Advantage: SebuahEksplorasi Model Konseptual. Badan Penerbit Universitas Diponegoro, Semarang.

[6]Griffin, J., 2009. Customer Loyality, Revisi. ed. Erlangga, Jakarta.

[7]Hair Jr, J. F., Hult, G. T. M., Ringle, C., and Sarstedt, M., 2016. A primer on partial least squares structural equation modeling (PLS-SEM). Sage Publications.

[8]Hunt, Shelby D., D.B.A. and S., 2006. The Explanatory Foundations of Relationship Marketing Theory. J. Bus. Ind. Mark. 21, 72-87.

[9]Kaplan, A.M. and, Haenlein, M., 2009. The Fairyland of Second Life: Virtual Social Worlds and How to Use Them [WWW Document]. Bus. Horiz. URL http://www.michaelhaenlein.com/Publications/Kaplan, Andreas - The fairyland of Second Life.pdf (accessed 5.25.14).

[10]Griffin, J., 2009. Customer Loyality, Revisi. ed. Erlangga, Jakarta.

[11]Kaplan, A.M. and, Haenlein, M., 2009. The Fairyland of Second Life: Virtual Social Worlds and How to Use Them [WWW Document]. Bus. Horiz. URL http://www.michaelhaenlein.com/Publications/Kaplan, Andreas - The fairyland of Second Life.pdf (accessed 5.25.14).

[12]Kotler, Philip and Amstrong, G., 2004. Principle of Marketing, 10th ed. Prentice Hall, New Jersey.

[13]Lee, J.s., Kim. S., and Pan, S., 2014. The Role of Relationship marketing investments in customer reciprocity. Int. J. Contemp. Hosp. Manag. 26, 5.

[14]McKee, S., 2010. Creative B2b Branding (No, Really): Building a Creative Brand in a Business World. Goodfellow Publishers Limited, USA.

[15]Morgan, R.M. and S.D.H., 1994. The Commitment-Trust Theory of Relationship Marketing. J. Mark. 58, 20-38.

[16]Murtiningsih, Dewi and AliMurad, A., 2016. The Effect of Social Media Marketingto Brand Loyalty (Case Study at the University Budi Luhur Jakarta). Int. J. Bus. Manag. Invent. 5, 50-53. 
[17]Ndubis, N.O., 2007. Relationship Marketing and Customer Loyalty. Mark. Intellegence\& Plan. $25,98-106$.

[18]Nguyen, T. U. H., Sherif, J. S. and Newby, M., 2007. Strategies for Successful CRM Implementation. Inf. Manag. Comput. Secur. 15, 102-115.

[19]Padmavathy; Balaji and Sivakumar, 2012. Measuring Effectiveness of Customer Relationship management In Indian Retail Banks. Int. J. Bank Mark. 30, 246-266.

[20]Porter; Michael, 1998. StrategiBersaing. Kharisma Publishing Group, Jakarta.

[21]Pudyanarti; Sri Kuning. Yuniati; Tri, 2016.I Pengaruh Keunggulan Kompetitif dengan loyalitas pelangganTerhadapEkspansiPasar. J. Ilmu dan Ris. Manaj. 5.

[22]Thomas, J.., Sullivan, U.., 2005. Managing Marketing Communication with Multichannel Customers. J. Mark. 69, 239-251.

[23]Verhoef, P.C., Lemon, K.N., 2013. Successful Customer Value Management: Key Lessons and Emerging Trend. Eur. Manag. J. 1-15.

[24]Zarella, 2010. The Social Media Marketing Book. O’Reilly Media Inc., CA, USA.

[25]Zikmund, G, W., Mcleod, Raymond, Gilbert, W, F., n.d. 2003.Customer Relationship Management: Integrating Marketing Strategy and Information Technology. John Wiley and Sons, Inc, USA. 